\title{
Ischemic Tolerance - Blessing or Curse
}

\author{
Jozef BURDA ${ }^{1}$, Rastislav BURDA ${ }^{2,3}$ \\ ${ }^{1}$ Institute of Neurobiology of Biomedical Research Center, Slovak Academy of Sciences, Košice, \\ Slovak Republic, ${ }^{2}$ Faculty of Medicine, Clinic of Trauma Surgery, P. J. Šafarik University, Košice, \\ Slovak Republic, ${ }^{3}$ University Hospital of L. Pasteur, Košice, Slovak Republic
}

Received January 13, 2021

Accepted July 21, 2021

Epub Ahead of Print September 10, 2021

\begin{abstract}
Summary
Application of knowledge about ischemic tolerance to clinic requires the solid understanding of mechanism of creation of this phenomenon. This review summarizes research that has been carried out in many laboratories over a long period of time, but the main focus will be on own experimental research. The main emphasis is devoted to the possibility of preparing full tolerance in the donor's body and its transfer to the patient in the form of activated blood plasma. Such plasma could be administered as soon as the patient is transported to the hospital and would take effect immediately after administration to the patient's bloodstream. One chapter is also devoted to anticonditioning, i.e. the possibility of preventing the activation of tolerance. Anticonditioning could be used to treat oncologic patients. We expect that this method could increase effectiveness of cancer treatment. Cross-tolerance with a wide range of diverse stressors gives us the courage to assume that activated plasma can significantly help with a wide range of pathological events.
\end{abstract}

\section{Key words}

Ischemic tolerance • Hippocampus • Neuroprotection • Remote ischemic postconditioning

\section{Corresponding author}

R. Burda, Faculty of Medicine, Clinic of Trauma Surgery, P. J. Šafárik University, Šrobárova 1014/2, 04001 Košice, Slovak Republic. E-mail: rastislav.burda@upjs.sk

\section{Introduction}

The study of adaptability has undergone significant evolution since Darwin, from the species through tissues, cells and molecules to genes (Gidday 2006). One of the forms of adaptability is the phenomenon of ischemic tolerance. This surprisingly strong body defense mechanism gives cells which have survived metabolic stress, or have undergone planned sublethal stress (preconditioning), the ability to become transiently resistant to subsequent, in other circumstances lethal stress.

This phenomenon was described for the first time in modern literature by Murry and colleagues, looking at the heart (Murry et al. 1986), and later by Kirino and colleagues in the brain (Kirino et al. 1991). Back in the $16^{\text {th }}$ century though, the toxicologist Paracelsus described for the first time the possibility that a serious noxious event might produce a state of tolerance (Pignataro et al. 2020). Equally, if we replace the term "tolerance" with "resistance", we find that the "multiresistance" known from the works of Paul Ehrlich, more than 100 years ago, is very close to "cross-tolerance". The existence of the phenomenon of tolerance has been demonstrated in all kinds of tissues, and for all species of the animal kingdom studied so far, including of course humans. It can be conceived as an evolutionary conserved form of defense mechanism (Dirnagl et al. 2003, Gidday 2006).

The decisive factor for activation of ischemic tolerance is a combination of two metabolic stresses (Burda et al. 2005, Burda et al. 2006). This phenomenon is a two-stage process: the first stress is absolutely necessary, but for full tolerance activation the occurrence 
of the second stress must also happen. A great advantage is that the two stresses do not have to be of the same nature (cross tolerance), and it does not matter whether they are applied to the whole body or only locally (remote tolerance).

Tolerance occurs in two modes:

- mild stress may be deliberately induced as the first stress (preconditioning), serving as protection against possible damage during surgery with planned ischemia of part of the organism;

- or the first stress is a pathological condition (heart attack, rupture or blockage of a blood vessel in the brain, whole-body ischemia or hypoxia, action of some poisons) and the second stress is therapeutic mild stress, i.e. postconditioning (as evidenced in hundreds of publications).

The strength of ischemic tolerance is documented in the following results: five minutes of global cerebral ischemia (four vessel occlusion (Pulsinelli and Brierley 1979)) in rats kills almost $40 \%$ of the most sensitive brain cells (CA1 of hippocampus) and ten minutes of brain ischemia leads to the death of almost $70 \%$ of these cells. A combination of these stresses, however, whether in an arrangement where the weaker ischemia comes first (as preconditioning) or, conversely, the stronger one is followed by the weaker (postconditioning), does not cause an accumulation of damage but, on the contrary, saves almost all of these cells (Burda et al. 2005, Burda et al. 2009, Burda et al. 2006).

The timing of the use of stress is extremely important. It is imperative to perform the second stress within the therapeutic window. This window is surprisingly long-lasting in the brain. Neurons die by apoptosis-like death, the onset and speed of which depends on the duration of previous ischemia, but also on body temperature. It has been documented that neurons can be rescued two days after the end of ischemia. This is made possible by so-called delayed death of neurons (Kirino 1982).

Two kinds of tolerance have been distinguished: "early" and "late". The early type starts just three to five minutes after preconditioning and lasts for approximately one hour (Perez-Pinzon et al. 1997), whereas "late" tolerance is activated two days after preconditioning and continues functioning for one week after its onset (Dirnagl et al. 2003). Rapid preconditioning induces transient and less strong neuroprotection than delayed preconditioning, and in addition, rapid preconditioning is not associated with "de-novo" protein synthesis (Barone et al. 1998, Burda et al. 2006, Dirnagl and Meisel 2008, Nishio et al. 1999). Delayed preconditioning is associated with longer molecular changes (Durukan and Tatlisumak 2010), including the de-novo synthesis of proteins, induction of transcription factors, and activation of antiapoptotic and antioxidant proteins (Brambrink et al. 2000, Toyoda et al. 1997). This 'delayed preconditioning' requires synthesis of new proteins, including inducible nitric oxide synthase (iNOS), cyclooxygenase-2 (COX-2) and heat-shock proteins (Burda et al. 2003, Riksen et al. 2004).

Protection can be provided by applying short periods of ischemia, hypoxia (Gage and Stanton 1996), hyperthermia (Chopp et al. 1989, Kitagawa et al. 1991), hypothermia (Nishio et al. 1999), cortical spreading depression (Kawahara et al. 1999, Matsushima et al. 1998), oxidative stress (Ohtsuki et al. 1992), hyperbaric oxygenation (Wada et al. 1996, Wada et al. 2000), norepinephrine (Meng et al. 1996, Ravingerova et al. 1995, Ravingerova et al. 2002), 3-nitropropionic acid (Brambrink et al. 2000, Kuroiwa et al. 2000, Riepe and Ludolph 1997, Sugino et al. 1999), lipopolysaccharide (Bordet et al. 2000, Puisieux et al. 2000, Tasaki et al. 1997), TNF-a (Chen et al. 2001), polyunsaturated fatty acids (Blondeau et al. 2002), volatile anesthetics (Siracusano et al. 2006), repeated magnetic stimulation (Fujiki et al. 2003), sound waves (Krokowicz et al. 2012, Tobalem et al. 2013), ionizing radiation (Kokosova et al. 2014), physical exercise (Chen et al. 2007), atorvastatin (Atar et al. 2006, Birnbaum et al. 2005, Chang et al. 2010), bradykinin (Danielisova et al. 2008, Goto et al. 1995) and kainic acid (Nagy et al. 2011).

Local stress application is fully sufficient for achieving whole body ischemic tolerance, for example stress in part of the body or part of an organ (Przyklenk et al. 1993), but also local, short-term ischemia by clamping a suitable artery or placing a tourniquet on the relevant limb (Dillon et al. 2006, Tsubota et al. 2010). Tolerance, after its activation, spreads to the whole body through the blood (Dickson et al. 1999, Wang et al. 2004). Moreover, Shimizu and colleagues (Shimizu et al. 2009) demonstrated cross-species tolerance transfer by means of blood plasma.

Activation of first-degree tolerance should be eliminated if the first stress is applied together with an opioid receptor blocker such as naloxone (Dickson et al. 2001), or if during activation of the first degree of tolerance, antioxidants or possibly scavengers of free 
oxygen radicals are administrated (Puisieux et al. 2004, Burda et al. 2009, Domorakova et al. 2009).

The effectiveness of tolerance is surprisingly strong even when the first stress is a pathological event and the second consists of moderate stress (postconditioning) applied within the therapeutic window, both in the heart (Zhao et al. 2003) and in the brain (Burda et al. 2006). The therapeutic window varies in different tissues, but it also depends on the kind of stress, its intensity and application time, and also on the temperature of the affected tissue.

The transition to the second stage, i.e. "full tolerance", occurs after a combination of two stresses, when the second occurs within $60 \mathrm{~min}$ of the first (rapid tolerance). However, the ability to activate full tolerance reappears again after two days of "maturing" of the first degree. If a second stress occurs during the activated first degree period, after about five hours, full tolerance proteins are synthesized (Burda et al. 2006). These proteins are able to penetrate into the brain from the blood through the blood-brain barrier (Burda et al. 2014), and they are universal, i.e. effective in the brain as well as muscles (Burda et al. 2019, Burda et al. 2020). Our preliminary results suggest that the duration of full tolerance is significantly shorter than that of the first degree.

The mechanism of the origin of tolerance needs to be studied after postconditioning, because preconditioning induces only the first stage with the production of triggers or mediators, while effectors reveal themselves only after the second stress. Due to the multiple damage caused by ischemia, the effect of the tolerance effector(s) must also trigger a whole cascade of changes.

\section{The basic conditions of survival include:}

Restoration of mitochondrial function. Mitochondria are fundamental as sources of energy, but also as sustainers of life, being elements involved in cell survival and death. They produce adenosine triphosphate (ATP) essential for each cell function. ATP is needed to maintain ionic gradients, contractile mechanisms and cellular integrity. Insufficient oxygen supply during ischemia inhibits electron flow along the respiratory chain, induces depolarization of the inner mitochondrial membrane, and limits ATP production.

Ischemia and reperfusion cause mitochondrial dysfunction that initiates the mitochondrial apoptosis pathway. The defining event in apoptosis is mitochondrial outer membrane permeabilization (MOMP), allowing apoptogen release. Bcl-2 family proteins Bax and Bak are the principal activators of MOMP and apoptosis. A series of pro-apoptotic proteins, including Bax, have been shown to increase mitochondrial outer membrane permeability. Under normal conditions, Bax is inactive in cytosol and is soluble or loosely attached to mitochondria. However, in response to apoptotic stimuli, Bax is translocated and inserted into the outer membrane, undergoes oligomerization, thereby inducing outer membrane permeability (Zhao et al. 2014). This pathway involves the release of cytochrome $\mathrm{c}$ and activation of the caspase cascade. The increase of cytochrome $\mathrm{c}$ in the cytosol is an indicator of cytochrome c release from mitochondria, activation of caspase- 3 and facilitated apoptosis (Niquet et al. 2006). The preservation of mitochondrial function represents an attractive strategy to reduce I/R-induced damage. Delayed postconditioning can be used as an effective tool able to prevent mitochondrial failure leading to apoptosis-like delayed neuronal death in postischemic rat hippocampus. Bradykinin as a postconditioner significantly attenuated ischemiainduced neuronal death, and also suppressed the release of MnSOD and cytochrome c from mitochondria, and prevented of caspase-3 activation (Danielisova et al. 2009).

Intramitochondrial calcium accumulation triggers permeability transition in the inner mitochondrial membrane (MPT), leading to production of reactive oxygen species, release of calcium, and increase in cytosol calcium concentration (Kristian and Siesjo 1996). $\mathrm{Na}^{+} / \mathrm{Ca}^{2+}$ exchanger (NCX) regulating the homeostasis of $\mathrm{Na}^{+}$and $\mathrm{Ca}^{2+}$ plays a key role in the evolution of ischemic neuronal damage (Annunziato et al. 2004, Pignataro et al. 2020). Another important role is played by mitochondrial component connexin 43 and mitochondrial permeability transition pores (Pagliaro et al. 2018).

In ischemia-vulnerable brain areas, such as the dorsolateral striatum or the CAl region, inhibition of protein synthesis is persistent (Bodsch et al. 1985, Dienel et al. 1980, Hu and Wieloch 1993, Widmann et al. 1991). Inhibition is due to phosphorylation of the eIF2 alpha subunit (Burda et al. 1994). Without recovery of protein synthesis, survival of cells is impossible.

Glutamate (Glu) levels in brain tissue and peripheral blood increase significantly following cerebral 
ischemia/reperfusion injury, and one of the basic actions of conditioning is to reduce its concentration (Paschen 1996, Saad et al. 2015, You et al. 2018, Zhang et al. 2011).

The mechanisms of postconditioning are still not clear. We deal in more detail with the mechanism of changes in the process of ischemic tolerance in our work (Lehotsky et al. 2009). An excellent review on this subject was written by Zhao and colleagues (Zhao et al. 2012). A good review focused on preconditioning was written by Hao and co-workers (Hao et al. 2020).

When the phenomenon of ischemic tolerance is associated with the treatment of pathological conditions (e.g. cerebral and cardiac ischemic events, trauma), a particular problem is the use of appropriate stressors. From the full range of possible biological, chemical and physical stressors (substances or treatments), it is very difficult to choose an appropriate procedure if the patient has suffered a heart attack, stroke or polytrauma. The use of local atraumatic tourniquet ischemia shows potential as a suitable method, although this approach also has its drawbacks in that it increases the blood pressure and flow-rate, which rules out its use in cases of bleeding into the brain.

Some other physical processes such as hyperthermia, hypothermia, sound waves and magnetic fields may be used as stressors. The good health of coldhardened people can be attributed to hypothermia in the body, which upon subcooling triggers the first stage of the ischemic tolerance phenomenon, so that when they come into contact with some second stress they activate the second degree, allowing them to overcome otherwise devastating pathological events without more damage. Similar status can also be achieved through use of the sauna, or other heat sources (even local).

Methods of local stress application started being used in clinical medicine as early as 2007 (Loukogeorgakis et al. 2007). Published results of clinical trials using remote postconditioning in the case of traumatic brain injury are unambiguously positive (Joseph et al. 2015).

However, the translation from numerous successful animal experiments to clinical practice has been disappointing to date. Most attempts have so far failed to reduce infarct size or improve clinical outcomes. (Heusch and Gersh 2017). There is a growing consensus that two risk factors are responsible for the failure of the IT mechanism, namely aging and comorbidity. The activity of enzymes as well as the effect of some drugs changes with age (Kaplan et al. 2019, Bartekova et al. 2016). The age-related diseases consist mainly of diabetes, hypertension and hyperlipidemia with concomitant comedication (statins, $\beta$-blockers, ACE inhibitors, angiotensin AT1 receptor antagonists (ARBs), calcium antagonists and nitrates). This situation is characteristic of patients with cardiovascular and cerebrovascular diseases (Ferdinandy et al. 2014, Przyklenk 2011, Tyagi et al. 2019).

\section{Blessing - possible uses of the ischemic tolerance phenomenon}

Uses of ischemic tolerance from the clinical point of view:

1. - for planned operations during which temporary cessation of the blood supply occurs. It is possible to use sublethal stress (preconditioning) and optimally 2-4 days after that to do surgery without imminent damage to the body from reduction or cessation of the blood supply, and with a significantly better result.

2. - as soon as possible after the pathological stress (hypoxia, ischemia, intoxication, trauma), to use reasonable moderate stress (postconditioning) if possible within the therapeutic window. A combination of other means of treatment can be used, with the exception of naloxone and antioxidants. It is possible to use local stress as postconditioning, e.g. short-term atraumatic ischemia of part of the limb.

3. - a revolutionary invention or idea should be mentioned, i.e. the combining of two appropriate mild stressors ("preconditioning" and "postconditioning") on an intact (young and healthy) donor. By applying these two stresses we can achieve full tolerance with the presence of end effectors in the donor's blood plasma. Active plasma, when administered to the endangered patient's blood, as opposed to conditioning, immediately begins to curtail the development of damage.

The use of active blood plasma or substances derived from it will make it possible to have medicine prepared in advance which can be administered into the patient's blood and take effect immediately during transport to the hospital, which can greatly improve the chances of success, especially in conditions threatening brain or heart damage. Administration of "activated plasma" should also reduce patients' discomfort caused by postconditioning application. Active plasma effectively prevents damage in skeletal muscle ischemia (Burda et al. 2020) as well as in ischemia and brain 
intoxication with trimethyltin (Burda et al. 2019). We expect activated plasma to be effective in the elderly and in patients with diabetes mellitus.

\section{The undesirable curse of ischemic tolerance}

Cancer treatment is exactly like the motto: what doesn't kill you makes you stronger. Chemotherapy and irradiation are also planned as lethal stress for target cells in cancer treatment. These treatments lead to death of the majority of target cells, but for the rest of cells and surrounding tissue they represent sublethal stress, which leads to activation of the first step of ischemic tolerance. If repeated doses of stress during the first degree of tolerance are used, activation of the full tolerance will occur. This will lead to transformation of some cancer cells transiently into resistant ones, which become inured to multiple lethal doses of chemotherapy or irradiation. In accordance with the cross-tolerance rule, activation will also occur if stressors of various types are used, e.g. a combination of chemotherapy with irradiation.

However, it has been repeatedly shown that the administration of antioxidants or oxygen radical scavengers effectively prevents the development of tolerance (Puisieux et al. 2004, Burda et al. 2009, Domoráková et al. 2009). The repeated application of chemotherapy combined with antioxidants would lead to cumulative death of undesirable cells.

We propose to take into account the knowledge gained in the study of ischemic tolerance and thus increase the effectiveness of cancer treatment. We expect that this technique could enable daily anticancer treatment and reduce the amount of drugs administered.

\section{Conclusions}

It should be emphasized that if an organism or part of an organism is exposed to stress which does not destroy it, the first phase of the defence mechanism will be temporarily activated. If this stress is lethal for one body part, it is usually only sublethal for the rest of the body. More precisely, the first stress initiates the first degree of tolerance, and the second stress full tolerance. The products of the first degree of activation circulate in the blood from a few days to two weeks, probably depending on the strength of the stress. If in this "window" there is a "collision" with the second stress, regardless of whether it is global or local, sublethal or lethal to some parts of the tissue, complete robust tolerance is activated. It then spreads to the whole body through the blood.

By testing "activated plasma" we demonstrated that this plasma is able to stop cell apoptosis after brain ischemia and also after muscle ischemia. This finding gives us hope that application of activated plasma or substances derived from it will be fully functional in the treatment of ischemic lesions of the brain and heart. Cross-tolerance with a wide range of diverse stressors encourages us to assume that activated plasma can significantly help with a wide range of pathological events.

Manufacturing of activated plasma in experimental animals is an easy procedure. Moreover, activated plasma is also fully functional in cross-species application, so we expect that it should be possible to produce it in animals without any need for killing them. Plasma does not lose activity either after freezing at $-80{ }^{\circ} \mathrm{C}$ or after lyophilisation. The following steps are necessary: select a suitable donor, choose the optimal conditioning method, remove unnecessary proteins from the plasma, and isolate the active substances.

\section{Conflict of Interest}

There is no conflict of interest.

\section{References}

ANNUNZIATO L, PIGNATARO G, Di RENZO GF: Pharmacology of brain Na+/Ca2+ exchanger: from molecular biology to therapeutic perspectives. Pharmacol Rev 56: 633-654, 2004. https://doi.org/10.1124/pr.56.4.5

ATAR S, YE Y, LIN Y, FREEBERG SY, NISHI SP, ROSANIO S, HUANG MH, URETSKY BF, PEREZ-POLO JR, BIRNBAUM Y: Atorvastatin-induced cardioprotection is mediated by increasing inducible nitric oxide synthase and consequent S-nitrosylation of cyclooxygenase-2. Am J Physiol Heart Circ Physiol 290: H1960-H1968, 2006. https://doi.org/10.1152/ajpheart.01137.2005

BARONE FC, WHITE RF, SPERA PA, ELLISON J, CURRIE RW, WANG X, FEUERSTEIN GZ: Ischemic preconditioning and brain tolerance: temporal histological and functional outcomes, protein synthesis requirement, and interleukin-1 receptor antagonist and early gene expression. Stroke 29: 1937-1950; discussion 1950-1931, 1998. https://doi.org/10.1161/01.str.29.9.1937 
BARTEKOVA M, RADOSINSKA J, PANCZA D, BARANCIK M, RAVINGEROVA T: Cardioprotective effects of quercetin against ischemia-reperfusion injury are age-dependent. Physiol Res 65 (Suppl 1): S101-S107, 2016. https://doi.org/10.33549/physiolres.933390

BIRNBAUM Y, YE Y, ROSANIO S, TAVACKOLI S, HU ZY, SCHWARZ ER, URETSKY BF: Prostaglandins mediate the cardioprotective effects of atorvastatin against ischemia-reperfusion injury. Cardiovasc Res 65 : 345-355, 2005. https://doi.org/10.1016/j.cardiores.2004.10.018

BLONDEAU N, WIDMANN C, LAZDUNSKI M, HEURTEAUX C: Polyunsaturated fatty acids induce ischemic and epileptic tolerance. Neuroscience 109: 231-241, 2002. https://doi.org/10.1016/s0306-4522(01)00473-0

BODSCH W, TAKAHASHI K, BARBIER A, OPHOFF BG, HOSSMANN KA: Cerebral protein synthesis and ischemia. Prog Brain Res 63: 197-210, 1985. https://doi.org/10.1016/S0079-6123(08)61984-6

BORDET R, DEPLANQUE D, MABOUDOU P, PUISIEUX F, PU Q, ROBIN E, MARTIN A, BASTIDE M, LEYS D, LHERMITTE M, DUPUIS B: Increase in endogenous brain superoxide dismutase as a potential mechanism of lipopolysaccharide-induced brain ischemic tolerance. J Cereb Blood Flow Metab 20: 1190-1196, 2000. https://doi.org/10.1097/00004647-200008000-00004

BRAMBRINK AM, SCHNEIDER A, NOGA H, ASTHEIMER A, GOTZ B, KORNER I, HEIMANN A, WELSCHOF M, KEMPSKI O: Tolerance-inducing dose of 3-nitropropionic acid modulates bcl-2 and bax balance in the rat brain: a potential mechanism of chemical preconditioning. J Cereb Blood Flow Metab 20: 1425-1436, 2000. https://doi.org/10.1097/00004647-200010000-00004

BURDA J, MARTIN ME, GARCIA A, ALCAZAR A, FANDO JL, SALINAS M: Phosphorylation of the alpha subunit of initiation factor 2 correlates with the inhibition of translation following transient cerebral ischaemia in the rat. Biochem J 302: 335-338, 1994. https://doi.org/10.1042/bj3020335

BURDA J, MATIASOVA M, GOTTLIEB M, DANIELISOVA V, NEMETHOVA M, GARCIA L, SALINAS M, BURDA R: Evidence for a role of second pathophysiological stress in prevention of delayed neuronal death in the hippocampal CA1 region. Neurochem Res 30: 1397-1405, 2005. https://doi.org/10.1007/s11064-005-8510-Z

BURDA J, DANIELISOVA V, NEMETHOVA M, GOTTLIEB M, KRAVCUKOVA P, DOMORAKOVA I, MECHIROVA E, BURDA R: Postconditioning and anticonditioning: possibilities to interfere to evoked apoptosis. Cell Mol Neurobiol 29: 821-825, 2009. https://doi.org/10.1007/s10571-009-9363-9

BURDA J, HREHOROVSKA M, BONILLA LG, DANIELISOVA V, CIZKOVA D, BURDA R, NEMETHOVA M, FANDO JL, SALINAS M: Role of protein synthesis in the ischemic tolerance acquisition induced by transient forebrain ischemia in the rat. Neurochem Res 28: 1213-1219, 2003. https://doi.org/10.1023/a:1024232513106

BURDA J, DANIELISOVA V, NEMETHOVA M, GOTTLIEB M, MATIASOVA M, DOMORAKOVA I, MECHIROVA E, FERIKOVA M, SALINAS M, BURDA R: Delayed postconditionig initiates additive mechanism necessary for survival of selectively vulnerable neurons after transient ischemia in rat brain. Cell Mol Neurobiol 26: 1141-1151, 2006. https://doi.org/10.1007/s10571-006-9036-X

BURDA R, DANIELISOVÁ V, BURDA J: The end effector of ischemic tolerance present in blood plasma from double conditioned donors ameliorates trimethyltin provoked damage in brain. OBM Neurobiology 3: 1-1, 2019. https://doi.org/10.21926/obm.neurobiol.1903041

BURDA R, MOROCHOVIC R, NEMETHOVA M, BURDA J: Remote ischemic postconditioning as well as blood plasma from double-conditioned donor ameliorate reperfusion syndrome in skeletal muscle. J Plast Surg Hand Surg 54: 59-65, 2020. https://doi.org/10.1080/2000656X.2019.1688163

BURDA R, DANIELISOVA V, GOTTLIEB M, NEMETHOVA M, BONOVA P, MATIASOVA M, MOROCHOVIC $\mathrm{R}$, BURDA J: Delayed remote ischemic postconditioning protects against transient cerebral ischemia/reperfusion as well as kainate-induced injury in rats. Acta Histochem 116: 1062-1067, 2014. https://doi.org/10.1016/j.acthis.2014.04.011

CHANG CZ, WU SC, LIN CL, HWANG SL, HOWNG SL, KWAN AL: Atorvastatin preconditioning attenuates the production of endothelin-1 and prevents experimental vasospasm in rats. Acta Neurochir (Wien) 152: 1399-1406; discussion 1405-1396, 2010. https://doi.org/10.1007/s00701-010-0652-3

CHEN HI, HSIEH SY, YANG FL, HSU YH, LIN CC: Exercise training attenuates septic responses in conscious rats. Med Sci Sports Exerc 39: 435-442, 2007. https://doi.org/10.1249/mss.0b013e31802d11c8 
CHEN Y, GINIS I, HALLENBECK JM: The protective effect of ceramide in immature rat brain hypoxia-ischemia involves up-regulation of bcl-2 and reduction of TUNEL-positive cells. J Cereb Blood Flow Metab 21: 34-40, 2001. https://doi.org/10.1097/00004647-200101000-00005

CHOPP M, CHEN H, HO KL, DERESKI MO, BROWN E, HETZEL FW, WELCH KM: Transient hyperthermia protects against subsequent forebrain ischemic cell damage in the rat. Neurology 39: 1396-1398, 1989. https://doi.org/10.1212/wnl.39.10.1396

DANIELISOVA V, GOTTLIEB M, NEMETHOVA M, BURDA J: Effects of bradykinin postconditioning on endogenous antioxidant enzyme activity after transient forebrain ischemia in rat. Neurochem Res 33: 1057-1064, 2008. https://doi.org/10.1007/s11064-007-9550-3

DANIELISOVA V, GOTTLIEB M, NEMETHOVA M, KRAVCUKOVA P, DOMORAKOVA I, MECHIROVA E, BURDA J: Bradykinin postconditioning protects pyramidal CA1 neurons against delayed neuronal death in rat hippocampus. Cell Mol Neurobiol 29: 871-878, 2009. https://doi.org/10.1007/s10571-009-9369-3

DICKSON EW, REINHARDT CP, RENZI FP, BECKER RC, PORCARO WA, HEARD SO: Ischemic preconditioning may be transferable via whole blood transfusion: preliminary evidence. J Thromb Thrombolysis 8: 123-129, 1999. https://doi.org/10.1023/a:1008911101951

DICKSON EW, BLEHAR DJ, CARRAWAY RE, HEARD SO, STEINBERG G, PRZYKLENK K: Naloxone blocks transferred preconditioning in isolated rabbit hearts. J Mol Cell Cardiol 33: 1751-1756, 2001. https://doi.org/10.1006/jmcc.2001.1436

DIENEL GA, PULSINELLI WA, DUFFY TE: Regional protein synthesis in rat brain following acute hemispheric ischemia. J Neurochem 35: 1216-1226, 1980. https://doi.org/10.1111/j.1471-4159.1980.tb07878.x

DILLON JP, LAING AJ, CHANDLER JR, WANG JH, MCGUINNESS A, REDMOND HP: Pravastatin attenuates tourniquet-induced skeletal muscle ischemia reperfusion injury. Acta Orthop 77: 27-32, 2006. https://doi.org/10.1080/17453670610045669

DIRNAGL U, MEISEL A: Endogenous neuroprotection: Mitochondria as gateways to cerebral preconditioning? Neuropharmacology 55: 334-344, 2008. https://doi.org/10.1016/j.neuropharm.2008.02.017

DIRNAGL U, SIMON RP, HALLENBECK JM: Ischemic tolerance and endogenous neuroprotection. Trends Neurosci 26: 248-254, 2003. https://doi.org/10.1016/S0166-2236(03)00071-7

DOMORAKOVA I, MECHIROVA E, DANKOVA M, DANIELISOVA V, BURDA J: Effect of antioxidant treatment in global ischemia and ischemic postconditioning in the rat hippocampus. Cell Mol Neurobiol 29: 837-844, 2009. https://doi.org/10.1007/s10571-009-9365-7

DURUKAN A, TATLISUMAK T: Preconditioning-induced ischemic tolerance: a window into endogenous gearing for cerebroprotection. Exp Transl Stroke Med 2: 2, 2010. https://doi.org/10.1186/2040-7378-2-2

FERDINANDY P, HAUSENLOY DJ, HEUSCH G, BAXTER GF, SCHULZ R: Interaction of risk factors, comorbidities, and comedications with ischemia/reperfusion injury and cardioprotection by preconditioning, postconditioning, and remote conditioning. Pharmacol Rev 66: 1142-1174, 2014. https://doi.org/10.1124/pr.113.008300

FUJIKI M, KOBAYASHI H, ABE T, KAMIDA T: Repetitive transcranial magnetic stimulation for protection against delayed neuronal death induced by transient ischemia. J Neurosurg 99: 1063-1069, 2003. https://doi.org/10.3171/jns.2003.99.6.1063

GAGE AT, STANTON PK: Hypoxia triggers neuroprotective alterations in hippocampal gene expression via a hemecontaining sensor. Brain Res 719: 172-178, 1996. https://doi.org/10.1016/0006-8993(96)00092-3

GIDDAY JM: Cerebral preconditioning and ischaemic tolerance. Nat Rev Neurosci 7: 437-448, 2006. https://doi.org/10.1038/nrn1927

GOTO M, LIU Y, YANG XM, ARDELL JL, COHEN MV, DOWNEY JM: Role of bradykinin in protection of ischemic preconditioning in rabbit hearts. Circ Res 77: 611-621, 1995. https://doi.org/10.1161/01.res.77.3.611

HAO Y, XIN M, FENG L, WANG X, WANG X, MA D, FENG J: Review cerebral ischemic tolerance and preconditioning: Methods, mechanisms, clinical applications, and challenges. Front Neurol 11: 812, 2020. https://doi.org/10.3389/fneur.2020.00812

HEUSCH G, GERSH BJ: The pathophysiology of acute myocardial infarction and strategies of protection beyond reperfusion: a continual challenge. Eur Heart J 38: 774-784, 2017. https://doi.org/10.1093/eurheartj/ehw224 
HU BR, WIELOCH T: Stress-induced inhibition of protein synthesis initiation: modulation of initiation factor 2 and guanine nucleotide exchange factor activities following transient cerebral ischemia in the rat. J Neurosci 13 : 1830-1838, 1993. https://doi.org/10.1523/JNEUROSCI.13-05-01830.1993

JOSEPH B, PANDIT V, ZANGBAR B, KULVATUNYOU N, KHALIL M, TANG A, O'KEEFFE T, GRIES L, VERCRUYSSE G, FRIESE RS, RHEE P: Secondary brain injury in trauma patients: the effects of remote ischemic conditioning. J Trauma Acute Care Surg 78: 698-703; discussion 703-695, 2015. https://doi.org/10.1097/TA.0000000000000584

KAPLAN P, TATARKOVA Z, LICHARDUSOVA L, KMETOVA SIVONOVA M, TOMASCOVA A, RACAY P, LEHOTSKY J: Age-associated changes in antioxidants and redox proteins of rat heart. Physiol Res 68: 883-892, 2019. https://doi.org/10.33549/physiolres.934170

KAWAHARA N, RUETZLER CA, MIES G, KLATZO I: Cortical spreading depression increases protein synthesis and upregulates basic fibroblast growth factor. Exp Neurol 158: 27-36, 1999. https://doi.org/10.1006/exnr.1999.7091

KIRINO T: Delayed neuronal death in the gerbil hippocampus following ischemia. Brain Res 239: 57-69, 1982. https://doi.org/10.1016/0006-8993(82)90833-2

KIRINO T, TSUJITA Y, TAMURA A: Induced tolerance to ischemia in gerbil hippocampal neurons. J Cereb Blood Flow Metab 11: 299-307, 1991. https://doi.org/10.1038/jcbfm.1991.62

KITAGAWA K, MATSUMOTO M, KUWABARA K, TAGAYA M, OHTSUKI T, HATA R, UEDA H, HANDA N, KIMURA K, KAMADA T: 'Ischemic tolerance' phenomenon detected in various brain regions. Brain Res 561: 203-211, 1991. https://doi.org/10.1016/0006-8993(91)91596-S

KOKOSOVA N, DANIELISOVA V, SMAJDA B, BURDA J: Ionizing radiation as preconditioning against transient cerebral ischemia in rats. Gen Physiol Biophys 33: 403-410, 2014. https://doi.org/10.4149/gpb 2014021

KRISTIAN T, SIESJO BK: Calcium-related damage in ischemia. Life Sci 59: 357-367, 1996. https://doi.org/10.1016/0024-3205(96)00314-1

KROKOWICZ L, KLIMCZAK A, CWYKIEL J, MIELNICZUK M, GRYKIEN C, SIEMIONOW M: Pulsed acoustic cellular expression as a protective therapy against $\mathrm{I} / \mathrm{R}$ injury in a cremaster muscle flap model. Microvasc Res 83: 213-222, 2012. https://doi.org/10.1016/j.mvr.2011.11.005

KUROIWA T, YAMADA I, ENDO S, HAKAMATA Y, ITO U: 3-Nitropropionic acid preconditioning ameliorates delayed neurological deterioration and infarction after transient focal cerebral ischemia in gerbils. Neurosci Lett 283: 145-148, 2000. https://doi.org/10.1016/s0304-3940(00)00937-x

LEHOTSKY J, BURDA J, DANIELISOVA V, GOTTLIEB M, KAPLAN P, SANIOVA B: Ischemic tolerance: the mechanisms of neuroprotective strategy. Anat Rec (Hoboken) 292: 2002-2012, 2009. https://doi.org/10.1002/ar.20970

LOUKOGEORGAKIS SP, WILLIAMS R, PANAGIOTIDOU AT, KOLVEKAR SK, DONALD A, COLE TJ, YELLON DM, DEANFIELD JE, MACALLISTER RJ: Transient limb ischemia induces remote preconditioning and remote postconditioning in humans by a K(ATP)-channel dependent mechanism. Circulation 116: 1386-1395, 2007. https://doi.org/10.1161/CIRCULATIONAHA.106.653782

MATSUSHIMA K, SCHMIDT-KASTNER R, HOGAN MJ, HAKIM AM: Cortical spreading depression activates trophic factor expression in neurons and astrocytes and protects against subsequent focal brain ischemia. Brain Res 807: 47-60, 1998. https://doi.org/10.1016/s0006-8993(98)00716-1

MENG X, CLEVELAND JC JR, ROWLAND RT, MITCHELL MB, BROWN JM, BANERJEE A, HARKEN AH: Norepinephrine-induced sustained myocardial adaptation to ischemia is dependent on alpha 1-adrenoceptors and protein synthesis. J Mol Cell Cardiol 28: 2017-2025, 1996. https://doi.org/10.1006/jmcc.1996.0194

MURRY CE, JENNINGS RB, REIMER KA: Preconditioning with ischemia: a delay of lethal cell injury in ischemic myocardium. Circulation 74: 1124-1136, 1986. https://doi.org/10.1161/01.cir.74.5.1124

NAGY D, KOCSIS K, FUZIK J, MAROSI M, KIS Z, TEICHBERG VI, TOLDI J, FARKAS T: Kainate postconditioning restores LTP in ischemic hippocampal CA1: onset-dependent second pathophysiological stress. Neuropharmacology 61: 1026-1032, 2011. https://doi.org/10.1016/j.neuropharm.2011.07.005

NIQUET J, SEO DW, WASTERLAIN CG: Mitochondrial pathways of neuronal necrosis. Biochem Soc Trans 34: 1347-1351, 2006. https://doi.org/10.1042/BST0341347 
NISHIO S, CHEN ZF, YUNOKI M, TOYODA T, ANZIVINO M, LEE KS: Hypothermia-induced ischemic tolerance. Ann N Y Acad Sci 890: 26-41, 1999. https://doi.org/10.1111/j.1749-6632.1999.tb07978.x

OHTSUKI T, MATSUMOTO M, KUWABARA K, KITAGAWA K, SUZUKI K, TANIGUCHI N, KAMADA T: Influence of oxidative stress on induced tolerance to ischemia in gerbil hippocampal neurons. Brain Res 599: 246-252, 1992. https://doi.org/10.1016/0006-8993(92)90398-s

PAGLIARO P, FEMMINO S, POPARA J, PENNA C: Mitochondria in cardiac postconditioning. Front Physiol 9: 287, 2018. https://doi.org/10.3389/fphys.2018.00287

PASCHEN W: Glutamate excitotoxicity in transient global cerebral ischemia. Acta Neurobiol Exp (Wars) 56: 313-322, 1996.

PEREZ-PINZON MA, XU GP, DIETRICH WD, ROSENTHAL M, SICK TJ: Rapid preconditioning protects rats against ischemic neuronal damage after 3 but not 7 days of reperfusion following global cerebral ischemia. J Cereb Blood Flow Metab 17: 175-182, 1997. https://doi.org/10.1097/00004647-199702000-00007

PIGNATARO G, BRANCACCIO P, LAUDATI G, VALSECCHI V, ANZILOTTI S, CASAMASSA A, CUOMO O, VINCIGUERRA A: Sodium/calcium exchanger as main effector of endogenous neuroprotection elicited by ischemic tolerance. Cell Calcium 87: 102183, 2020. https://doi.org/10.1016/j.ceca.2020.102183

PRZYKLENK K: Efficacy of cardioprotective 'conditioning' strategies in aging and diabetic cohorts: the co-morbidity conundrum. Drugs Aging 28: 331-343, 2011. https://doi.org/10.2165/11587190-000000000-00000

PRZYKLENK K, BAUER B, OVIZE M, KLONER RA, WHITTAKER P: Regional ischemic 'preconditioning' protects remote virgin myocardium from subsequent sustained coronary occlusion. Circulation 87: 893-899, 1993. https://doi.org/10.1161/01.cir.87.3.893

PUISIEUX F, DEPLANQUE D, PU Q, SOUIL E, BASTIDE M, BORDET R: Differential role of nitric oxide pathway and heat shock protein in preconditioning and lipopolysaccharide-induced brain ischemic tolerance. Eur J Pharmacol 389: 71-78, 2000. https://doi.org/10.1016/s0014-2999(99)00893-6

PUISIEUX F, DEPLANQUE D, BULCKAEN H, MABOUDOU P, GELE P, LHERMITTE M, LEBUFFE G, BORDET $\mathrm{R}$ : Brain ischemic preconditioning is abolished by antioxidant drugs but does not up-regulate superoxide dismutase and glutathion peroxidase. Brain Res 1027: 30-37, 2004. https://doi.org/10.1016/j.brainres.2004.08.067

PULSINELLI WA, BRIERLEY JB: A new model of bilateral hemispheric ischemia in the unanesthetized rat. Stroke 10: 267-272, 1979. https://doi.org/10.1161/01.str.10.3.267

RAVINGEROVA T, PYNE NJ, PARRATT JR: Ischaemic preconditioning in the rat heart: the role of G-proteins and adrenergic stimulation. Mol Cell Biochem 147: 123-128, 1995. https://doi.org/10.1007/BF00944792

RAVINGEROVA T, PANCZA D, ZIEGELHOFFER A, STYK J: Preconditioning modulates susceptibility to ischemia-induced arrhythmias in the rat heart: the role of alpha-adrenergic stimulation and $\mathrm{K}(\mathrm{ATP})$ channels. Physiol Res 51: 109-119, 2002.

RIEPE MW, LUDOLPH AC: Chemical preconditioning: a cytoprotective strategy. Mol Cell Biochem 174: 249-254, 1997.

RIKSEN NP, SMITS P, RONGEN GA: Ischaemic preconditioning: from molecular characterisation to clinical application--part I. Neth J Med 62: 353-363, 2004.

SAAD MA, ABDELSALAM RM, KENAWY SA, ATTIA AS: Ischemic preconditioning and postconditioning alleviates hippocampal tissue damage through abrogation of apoptosis modulated by oxidative stress and inflammation during transient global cerebral ischemia-reperfusion in rats. Chem Biol Interact 232: 21-29, 2015. https://doi.org/10.1016/j.cbi.2015.03.007

SHIMIZU M, TROPAK M, DIAZ RJ, SUTO F, SURENDRA H, KUZMIN E, LI J, GROSS G, WILSON GJ, CALLAHAN J, REDINGTON AN: Transient limb ischaemia remotely preconditions through a humoral mechanism acting directly on the myocardium: evidence suggesting cross-species protection. Clin Sci (Lond) 117: 191-200, 2009. https://doi.org/10.1042/CS20080523

SIRACUSANO L, GIRASOLE V, ALVARO S, CHIAVARINO ND: Myocardial preconditioning and cardioprotection by volatile anaesthetics. J Cardiovasc Med (Hagerstown) 7: 86-95, 2006. https://doi.org/10.2459/01.JCM.0000199792.32479.ce

SUGINO T, NOZAKI K, TAKAGI Y, HASHIMOTO N: 3-Nitropropionic acid induces ischemic tolerance in gerbil hippocampus in vivo. Neurosci Lett 259: 9-12, 1999. https://doi.org/10.1016/s0304-3940(98)00875-1 
TASAKI K, RUETZLER CA, OHTSUKI T, MARTIN D, NAWASHIRO H, HALLENBECK JM: Lipopolysaccharide pre-treatment induces resistance against subsequent focal cerebral ischemic damage in spontaneously hypertensive rats. Brain Res 748: 267-270, 1997. https://doi.org/10.1016/s0006-8993(96)01383-2

TOBALEM M, WETTSTEIN R, PITTET-CUENOD B, VIGATO E, MACHENS HG, LOHMEYER JA, REZAEIAN F, HARDER Y: Local shockwave-induced capillary recruitment improves survival of musculocutaneous flaps. J Surg Res 184: 1196-1204, 2013. https://doi.org/10.1016/j.jss.2013.03.040

TOYODA T, KASSELL NF, LEE KS: Induction of ischemic tolerance and antioxidant activity by brief focal ischemia. Neuroreport 8: 847-851, 1997. https://doi.org/10.1097/00001756-199703030-00008

TSUBOTA H, MARUI A, ESAKI J, BIR SC, IKEDA T, SAKATA R: Remote postconditioning may attenuate ischaemia-reperfusion injury in the murine hindlimb through adenosine receptor activation. Eur $\mathrm{J}$ Vasc Endovasc Surg 40: 804-809, 2010. https://doi.org/10.1016/j.ejvs.2010.08.014

TYAGI S, SINGH N, VIRDI JK, JAGGI AS: Diabetes abolish cardioprotective effects of remote ischemic conditioning: evidences and possible mechanisms. J Physiol Biochem 75: 19-28, 2019. https://doi.org/10.1007/s13105-01900664-W

WADA K, ITO M, MIYAZAWA T, KATOH H, NAWASHIRO H, SHIMA K, CHIGASAKI H: Repeated hyperbaric oxygen induces ischemic tolerance in gerbil hippocampus. Brain Res 740: 15-20, 1996. https://doi.org/10.1016/s0006-8993(96)00831-1

WADA K, MIYAZAWA T, NOMURA N, YANO A, TSUZUKI N, NAWASHIRO H, SHIMA K: Mn-SOD and Bcl-2 expression after repeated hyperbaric oxygenation. Acta Neurochir Suppl 76: 285-290, 2000. https://doi.org/10.1007/978-3-7091-6346-7_59

WANG WZ, STEPHESON LL, FANG XH, KHIABANI KT, ZAMBONI WA: Ischemic preconditioning-induced microvascular protection at a distance. J Reconstr Microsurg 20: 175-181, 2004. https://doi.org/10.1055/s-2004$\underline{820775}$

WIDMANN R, KUROIWA T, BONNEKOH P, HOSSMANN KA: [14C]leucine incorporation into brain proteins in gerbils after transient ischemia: relationship to selective vulnerability of hippocampus. J Neurochem 56: 789-796, 1991. https://doi.org/10.1111/j.1471-4159.1991.tb01993.x

YOU J, FENG L, XIN M, MA D, FENG J: Cerebral ischemic postconditioning plays a neuroprotective role through regulation of central and peripheral glutamate. Biomed Res Int 2018: 6316059, 2018. https://doi.org/10.1155/2018/6316059

ZHANG WQ, MIAO YF, ZHOU SQ, JIANG JY, LUO QZ, QIU YM: Neuroprotective effects of ischemic postconditioning on global brain ischemia in rats through upregulation of hippocampal glutamine synthetase. J Clin Neurosci 18: 685-689, 2011. https://doi.org/10.1016/j.jocn.2010.08.027

ZHAO H, REN C, CHEN X, SHEN J: From rapid to delayed and remote postconditioning: the evolving concept of ischemic postconditioning in brain ischemia. Curr Drug Targets 13: 173-187, 2012. https://doi.org/10.2174/138945012799201621

ZHAO ZQ, CORVERA JS, HALKOS ME, KERENDI F, WANG NP, GUYTON RA, VINTEN-JOHANSEN J: Inhibition of myocardial injury by ischemic postconditioning during reperfusion: comparison with ischemic preconditioning. Am J Physiol Heart Circ Physiol 285: H579-H588, 2003. https://doi.org/10.1152/ajpheart.01064.2002

ZHAO YX, CUI M, CHEN SF, DONG Q, LIU XY: Amelioration of ischemic mitochondrial injury and Bax-dependent outer membrane permeabilization by Mdivi-1. CNS Neurosci Ther 20:528-538, 2014. https://doi.org/10.1111/cns.12266 